\title{
Congenital dyserythropoietic anaemia: response to splenectomy and quantitation of ineffective erythropoiesis
}

\author{
DIANA SAMSON ${ }^{1}$, D. HALLIDAY ${ }^{2}$, AND I. CHANARIN 1 \\ From the Department of Haematology ${ }^{1}$ and Division of Clinical Investigation ${ }^{2}$, Northwick Park Hospital \\ and Clinical Research Centre, Watford Road, Harrow, Middlesex
}

SUMMARY The clinical and haematological features of an unusual case of congenital dyserythro-i poietic anaemia are described. There was a pronounced haemolytic component to the anaemia, $\vec{\infty}$ with a mean cell life of five days, and a remarkable response to splenectomy. Measurement of the $e^{+}$ incorporation of ${ }^{15} \mathrm{~N}$ glycine into the haem of circulating red cells and into bilirubin showed that haem turnover due to ineffective erythropoiesis was increased 45 times compared with a control ${ }_{T}^{-}$ group $(11.63 \mathrm{mg} / \mathrm{kg} /$ day, $\mathrm{NR}=0.26 \pm 0.10)$ and represented $51 \%$ of total erythroid haem turnover.

Heimpel and Wendt (1968) defined three types of congenital dyserythropoietic anaemia: type 1 , megaloblastic erythropoiesis with internuclear chromatin bridges (Wendt and Heimpel, 1967; Heimpel et al., 1971); type II, hereditary erythroblastic multinuclearity with a positive acidified serum test (HEMPAS) (Crookston, et al., 1969; Verwilghen et al., 1973); and type III, erythroblastic multinuclearity and gigantoblasts (Wolff and Von Hofe, 1951; Bergström and Jacobsson, 1962; Goudsmit et al., 1972). Other congenital dyserythropoietic syndromes have been described by Valentine et al. (1973) and Weatherall et al. (1973).

The present report describes the clinical and haematological features of a patient with severe congenital dyserythropoietic anaemia (CDA) which does not fall into any of the above categories, and in whom there was a remarkable response to splenectomy. In order to quantitate the degree of ineffective erythropoiesis the incorporation of ${ }^{15} \mathrm{~N}$ glycine into the haem of circulating red cells and into bile pigment was measured.

\section{Case report}

$\mathrm{NE}$, the youngest of four children, was born after a

Requests for reprints: Dr. I. Chanarin, Department of Haematology, Northwick Park Hospital and Clinical Research Centre, Watford Road, Harrow, Middlesex, HA1 3UJ

Received for publication 21 June 1976 normal pregnancy and delivery. Anaemia ande hepatosplenomegaly were first noted at 8 wee 8 . $V$ Both liver and spleen were palpable $3 \mathrm{~cm}$ below costal margin. There was no lymphadenopathy añid he was not clinically jaundiced. There was nos relevant family history. Initial investigations weren as follows: Hb $3.9 \mathrm{~g} / \mathrm{dl}$, MCV $76 \mathrm{fl}$, total WBCD $18,900 / \mu 1$, neutrophils $11,900 / \mu 1$, lymphocytes $7,300 /$ $\mu 1$, monocytes $200 / \mu 1$, eosinophils $400 / \mu 1$, occasionalo myelocytes and metamyelocytes, nucleated red cells ${ }^{3}$ $180 / 100$ WBC, reticulocytes $7.0 \%$, and platelets $160,000 / \mu 1$. The peripheral blood (Fig. 1) showed marked anisocytosis and poikilocytosis, spherocytes $\frac{0}{0}$ schistocytes, polychromasia, Howell-Jolly bodies, and basophil stippling. The marrow (Fig. 2) was. hypercellular with marked erythroid hyperplasia, 0 normoblastic erythropoiesis, and gross dyshaemo poiesis. A few binucleate erythroblasts were present? at all stages of development but were not a prominent feature, and cells containing more than two nucle? were rare. There were also numerous smear cells and reticulum cells, some showing erythrophagocytosis: Iron stores were normal and there were no ring sideroblasts. The following further investigations were carried out, mainly during the first 6 months of life. The estimated mean cell life of the patient'so own cells, using ${ }^{51} \mathrm{Cr}$ labelling and the elution corrections of Garby and Mollison (1971), was fives? days while that of compatible donor cells was 800 days. Surface counting was not carried out, so thato no data are available on splenic sequestration $\mathbb{Q}$ Osmotic fragility was increased, the patient's cells 


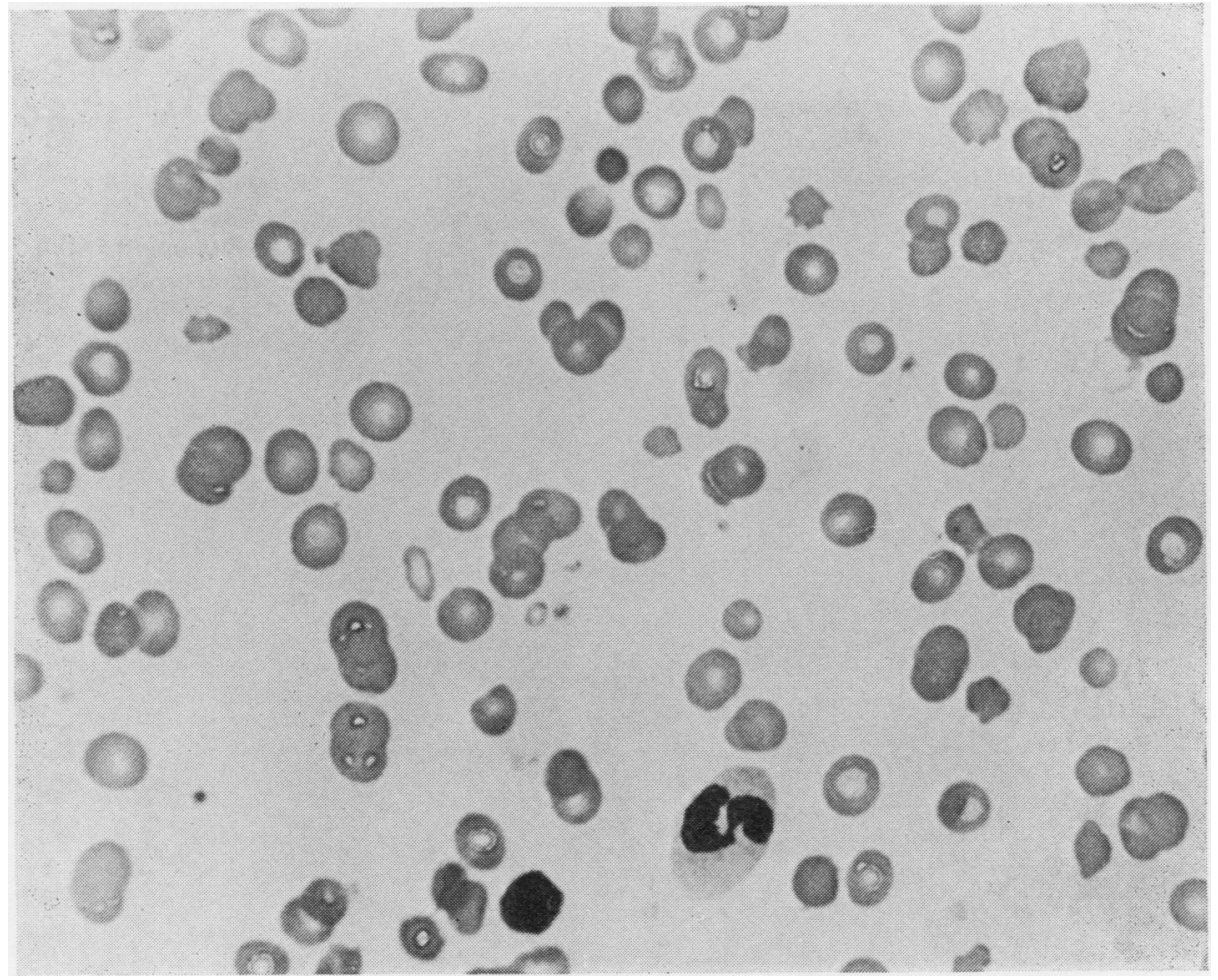

Fig. 1 Peripheral blood before splenectomy showing gross anisopoikilocytosis $(\times 855)$.

showing $65-70 \%$ lysis in $0.45 \%$ saline. Autohaemolysis varied from $7 \cdot 1 \%$ to $8.8 \%$ without glucose, and from 2.0 to $5.9 \%$ with added glucose. Red cell folate was $180 \mu \mathrm{g} / \mathrm{l}$ (normal range 150-450), serum iron $55.9 \mu \mathrm{mol} / 1$ (NR 12-27), and iron binding capacity $71.4 \mu \mathrm{mol} / 1$ (NR 40-75). Total bilirubin was $8 \mu \mathrm{mol} / \mathrm{l}$ (NR 2-15). (Only one estimation was done at this time, and it is probably spuriously low, since after splenectomy the bilirubin is persistently slightly elevated at 20-25 $\mu \mathrm{mol} / \mathrm{l}$ ). Serum haptoglobins were absent. The direct antiglobulin test was negative and the serum contained no atypical antibodies. $\mathrm{Hb}$ electrophoresis was normal on starch, paper, and cellulose acetate. $\mathrm{Hb} F$ was $2.8 \%$ at age 5 months, which is within normal limits, $\mathrm{Hb} \mathrm{A}_{2}$ was $2.0 \%$, and measurement of globin chain synthesis showed a ratio of $\alpha: \beta+\gamma$ of 0.98 . Ham's acidified serum lysis test was negative using a total of seven different normal sera on four different occasions and the sucrose lysis test was consistently negative. Cold antibody lysis was $43 \%$ and $67 \%$ on two occasions using anti-I serum diluted 1:100 in fresh normal serum. There was increased $i$ antigen on the patient's cells (agglutination titres with known anti-i serum: patient: $1: 512$, adult control: $1: 8$, cord control: $1: 2,000$ ).

The following enzymes were assayed: Glucose phosphate isomerase, phosphofructokinase, fructose diphosphate aldolase, triosephosphate isomerase, glyceraldehyde phosphate dehydrogenase, monophosphoglyceromutase, phosphopyruvate hydratase, pyruvate kinase, lactate dehydrogenase, glutathione reductase, glutathione peroxidase, and adenylate kinase. The enzyme patterns were those expected for the level of reticulocytosis and no deficiency was found. 2,3 DPG was $2 \cdot 15 \mu \mathrm{mol} / \mathrm{ml}$ packed red cells (NR 2.28-4·76). Electron microscopy of peripheral blood and marrow cells showed no abnormality. Electrophoretic analysis of red cell membrane proteins was qualitatively normal. Thymidine labelling indices were just outside the normal range: basophilic erythroblasts $73 \%$ (NR 58-70), early polychromatic erythroblasts $70 \%$ (NR 77-85), excluding a major kinetic disturbance. Porphyrin estimations were as follows: urinary coproporphyrin $134 \mu \mathrm{g} /$ day (NR 0-161), urinary uroporphyrin $47 \mu \mathrm{g} /$ day (NR 5-30), faecal coproporphyrin $35 \mu \mathrm{g} / \mathrm{g}$ dry stool (NR 0-20), and faecal protoporphyrin $16 \mu \mathrm{g} / \mathrm{g}$ dry stool (NR 0-76). The raised urinary uroporphyrin and faecal coproporphyrin are compatible with haemolytic anaemia and do not indicate a primary disturbance of porphyrin metabolism. Serum immunoglobulin levels were as follows: IgG $1.0 \mathrm{~g} / 1$, IgA $0.9 \mathrm{~g} / 1$, IgM $0.3 \mathrm{~g} / 1$ (95\% NR 0-1 yr 


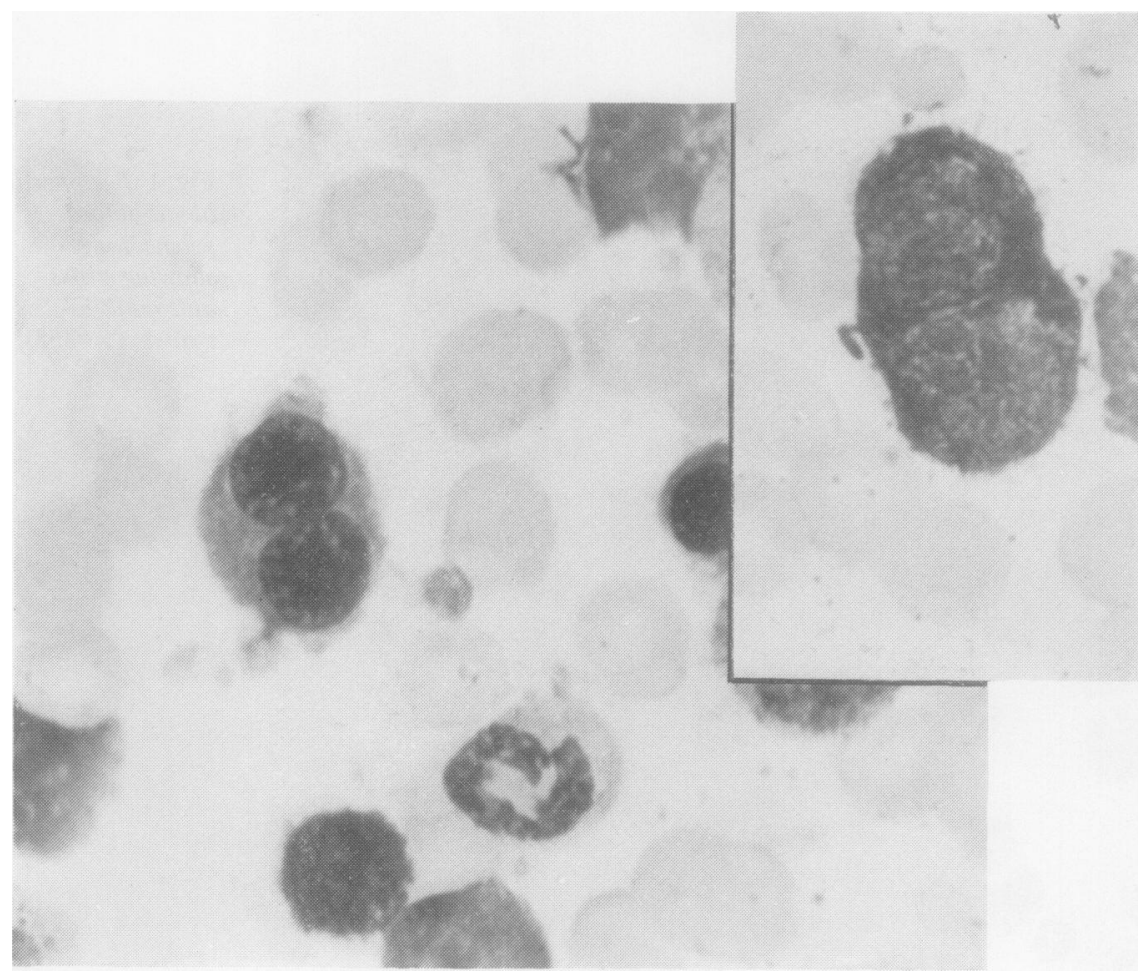

Fig. 2 Two

binucleate erythroblasts from the marrow $(\times 1000)$. (inset $\times$ 7000)

in this laboratory: $\operatorname{IgG} 3 \cdot 0-13 \cdot 6 \mathrm{~g} / 1, \operatorname{IgA} 0 \cdot 3-1 \cdot 3 \mathrm{~g} / \mathrm{l}$, IgM $0 \cdot 3-2 \cdot 3 \mathrm{~g} / \mathbf{l})$. Urea and electrolytes, urinary amino acids, chest $\mathrm{x}$-ray, skeletal survey, and intravenous pyelogram were all normal. Chromosomal analysis of blood/marrow cells was not performed.

The patient was transfused soon after admission and subsequently at approximately monthly intervals. He was given desferrioxamine with each transfusion and folic acid supplements. A one-month course of prednisone, $2 \mathrm{mg} / \mathrm{kg} / \mathrm{day}$, had no effect on the anaemia or reticulocyte count. Soon after the first transfusion the nucleated red cells fell to between 0 and 5/100 WBC and remained at low levels. The white count fell to normal and the myelocytes and metamyelocytes disappeared from the peripheral blood. The reticulocyte count varied between 0 and $10 \%$ but was usually normal (Fig. 3 ), often being less than $1 \%$. In May 1973, when the patient was aged $2 \frac{1}{2}$, elective splenectomy was performed. The spleen weighed $333 \mathrm{~g}$ and histology showed congestion only. Soon after splenectomy the haemoglobin rose to $13.5 \mathrm{~g} / \mathrm{dl}$ and has subsequently remained between 12 and $13.5 \mathrm{~g} / \mathrm{dl}$. The reticulocyte count also rose to levels between $13 \%$ and $20 \%$ and the mean cell life of the patient's own cells rose to 21 days. Immunoglobulin levels have remained low: IgG $3.3 \mathrm{~g} / 1$, IgA $0.9 \mathrm{~g} / 1, \mathrm{IgM} 0.3 \mathrm{~g} / \mathrm{l}$ at age 3 years and 6 months, and
IgG $4.5 \mathrm{~g} / 1, \operatorname{IgA} 1.0 \mathrm{~g} / \mathrm{l}, \operatorname{IgM} 0.3 \mathrm{~g} / 1$ at age 4 years 11 months (95\% NR 1-7 yr in this laboratory:

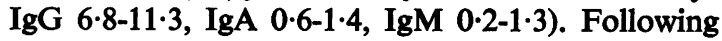
splenectomy the patient has been maintained on prophylactic oral penicillin and folic acid supplements and has been quite well apart from one episode of tonsillitis. The liver remains enlarged $4 \mathrm{~cm}$ below the costal margin, but growth and development have been otherwise normal and no further transfusion has been required. The haematological parameters before and after splenectomy are shown in Fig. 3 and the post-splenectomy blood film in Figure 4.

${ }^{15}$ N GLYCINE STUDY

This was carried out six months after splenectomy when a steady state had been achieved. Informed o consent was given by the parents and the study was $N$ approved by the Hospital Ethical Committee. The $\underset{\omega}{N}$ experimental design and methods were as previously described (Samson et al., 1976b) with the following modifications:

1. It was not feasible to perform a ${ }^{14} \mathrm{C}$ bilirubin $\stackrel{\mathcal{Q}}{?}$ clearance in such a young child. Total bilirubin production rate was therefore calculated by equating the disappearance of labelled glycine from the circulating red cells with its appearance in bile 


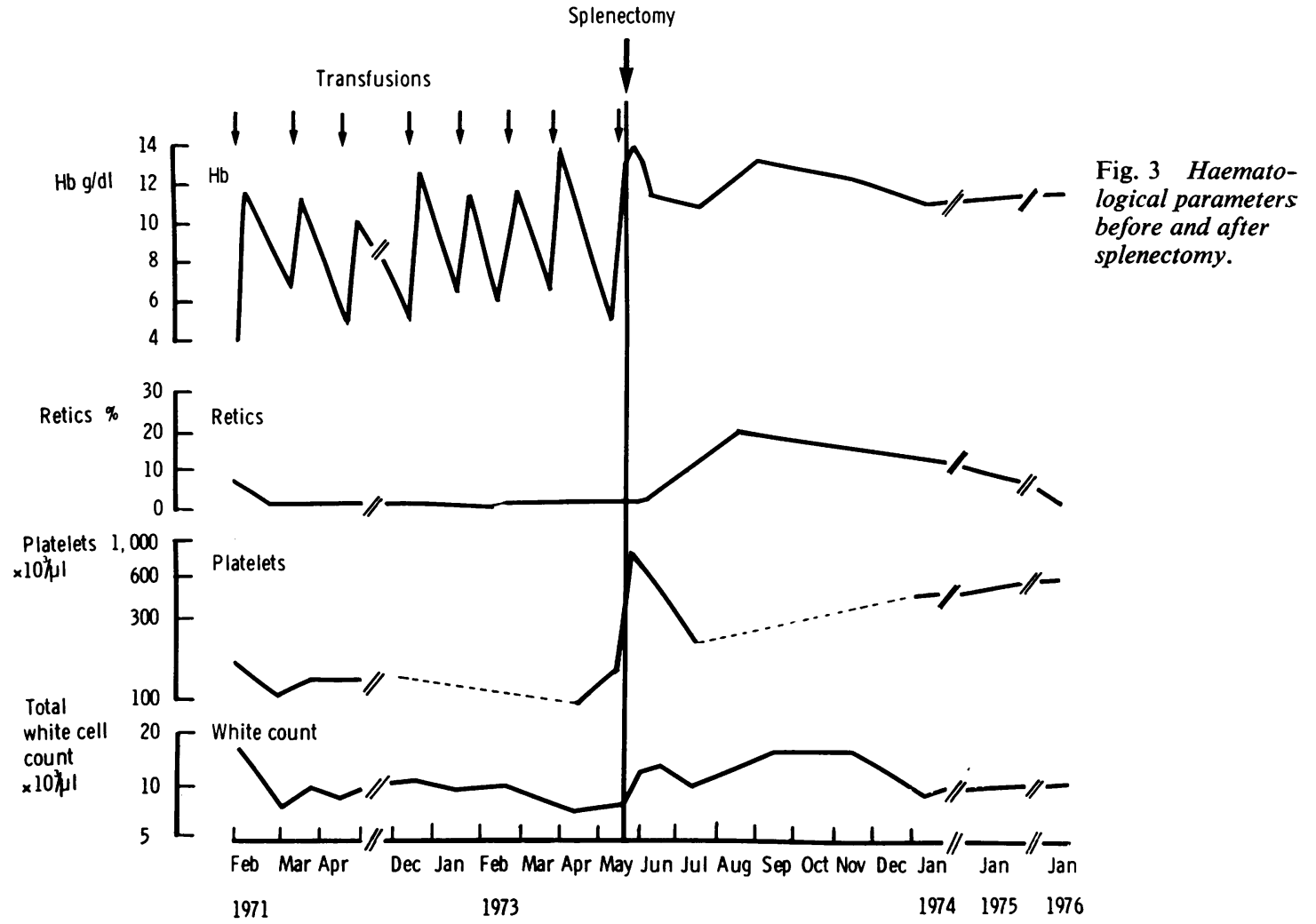

pigment. This necessitated prolonging the study period.

2. In view of the enormous increase in erythroid haem turnover, it was not considered necessary to quantitate hepatic haem turnover by measuring the incorporation of $\delta$-aminolaevulinic acid into early labelled bilirubin.

\section{CALCULATION OF BILIRUBIN PRODUCTION RATE (BRP)}

The incorporation of the administered glycine $(80 \mathrm{mg}$ of 98.5 atom $\%$ excess ${ }^{15} \mathrm{~N}$ ) on day $\mathrm{x}=$

$\mathrm{BRP} \times 8 \times \mathrm{MW}$ glycine $\times$ atom $\%$ excess bilirubin day $\mathrm{x} / \mathrm{MW}$ bilirubin $\times 80 \times 98.5=0.0128 \times \mathrm{BRP}$ $x$ atom $\%$ excess ${ }^{15} \mathrm{~N}$ bilirubin day $\mathrm{x}$.

Assuming that all labelled bilirubin produced after day 17 is derived from destruction of circulating red cells (see Fig. 5)

$\sum_{x=18}^{x=24}$ incorporation glycine into bilirubin $=\%$

incorporation glycine into $\mathrm{Hb}$ haem day $17-$ $\%$ incorporation glycine into $\mathrm{Hb}$ haem day 24 .

$$
\begin{aligned}
& 0.0128 \times \operatorname{BRP} \times \sum_{x=18}^{x=24} \text { atom } \% \text { excess }{ }^{15} \mathrm{~N} \text { bilirubin }= \\
& 2 \cdot 17-1 \cdot 57 \mathrm{BRP}=330 \mathrm{mg} / \text { day. }
\end{aligned}
$$

CALCULATION OF \% INCORPORATION INTO EARLY LABELLED BILIRUBIN

The $\%{ }^{15} \mathrm{~N}$ glycine lost from peripheral blood haem daily between day 7 and day 17 was derived from the graph (Fig. 5). This would give rise to an equal \% ${ }^{15} \mathrm{~N}$ glycine incorporation into bilirubin on that day which was therefore subtracted from the total $\%{ }^{15} \mathrm{~N}$ glycine incorporation into bilirubin to give the $\%{ }^{15} \mathrm{~N}$ glycine incorporated into early labelled bilirubin (Table). From the graph the apparent mean cell life of the cells labelled with ${ }^{15} \mathrm{~N}$ is shown to be 27 days, compared with a mean cell life of 21 days determined by ${ }^{51} \mathrm{Cr}$ survival, indicating reutilisation of ${ }^{15} \mathrm{~N}$ glycine for haem synthesis which would be associated with further excretion of labelled bilirubin. For this reason the early labelled bilirubin relating to the synthesis of the initial cohort of red cells is considered to end at day 10 . The total \% incorporation of ${ }^{15} \mathrm{~N}$ glycine into the early labelled bilirubin days $0-10\left(\mathrm{G}_{\mathrm{ELP}}\right)$ was $2 \cdot 83 \%$.

\section{FURTHER PARAMETERS}

$B R_{R B C}$ and $B R_{I E}$, bilirubin production from red cell destruction and from ineffective erythropoiesis, and the percentage ineffective erythropoiesis were calculated as previously described (Samson et al., 


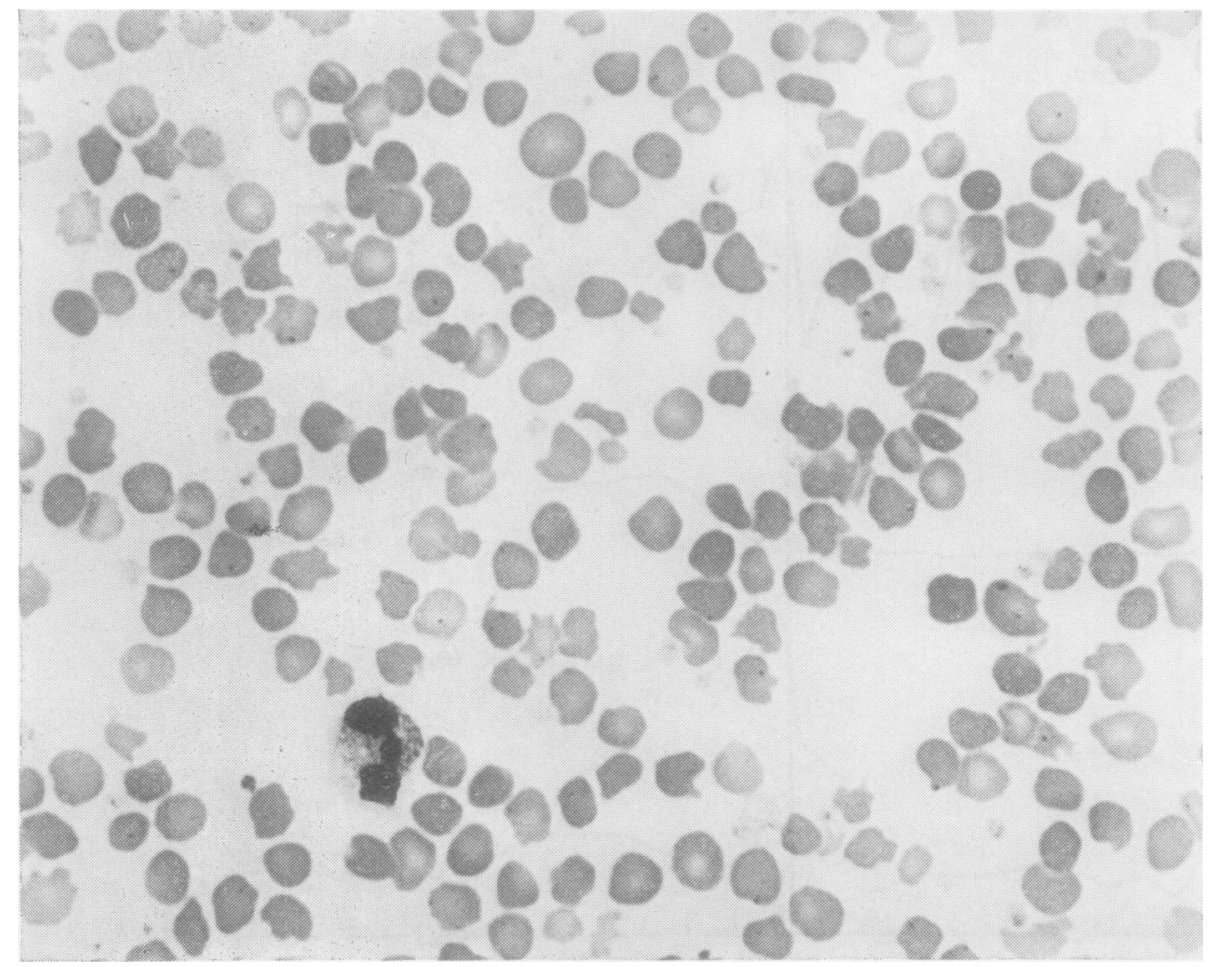

Fig. 4 Peripheral blood after splenectomy showing persistence of original abnormalities and $\rightarrow$ post-splenectomy $\vec{\omega}$ change.

1976b), assuming that $\mathrm{BR}_{\mathrm{HEP}}$, bilirubin production from hepatic haem turnover, was $0.76 \mathrm{mg} / \mathrm{kg} /$ day (mean normal value) (Berk et al., 1976). Haem turnover rates were calculated by converting bilirubin production rates to molar units.

\section{Results}

These are summarised in Fig. 5 and the Table.

\section{Discussion}

CLINICAL AND HAEMATOLOGICAL FEATURES The morphology of the bone marrow in the present case is unlike that seen in any of the types of CDA defined by Heimpel and Wendt (1968). Erythropoiesis was normoblastic, there were no internuclear chromatin bridges or giant cells, and multinucleate cells were not a prominent feature. The acidified $\varrho$ serum test was negative, and increased cold antibody $\overrightarrow{\overrightarrow{0}}$ lysis and increased agglutinability by anti-i are nonspecific features of many dyserythropoietic anaemias.

It is likely that CDA may result from a variety of underlying abnormalities of structure or function of erythroid cells. It was not possible to demonstrate $:$ any specific abnormality in the present case.

The excellent response to splenectomy in the present case is undoubtedly related to the severity of the haemolysis, which is an unusual feature of 0 CDA. In the majority of reported cases there was only a moderate reduction in red cell survivalo (Crookston et al., 1969; Verwilghen et al., 1973). However, in one case described by Verwilghen et $\stackrel{\sim}{\circ}$ al. (1973), the $\mathrm{T}_{\frac{1}{2}}{ }^{51} \mathrm{Cr}$ was $7 \cdot 25$ days and splenectomy

Table Haem turnover and ineffective erythropoiesis

\begin{tabular}{|c|c|c|c|c|c|}
\hline \multirow[t]{2}{*}{ Subject } & \multicolumn{4}{|c|}{ Bilirubin production/haem turnover $\left(\mu \mathrm{mol} \mathrm{kg} \mathrm{kg}^{-1}\right.$ day-1) $\left.^{-1}\right)$} & \multirow{2}{*}{$\begin{array}{l}\text { Percentage ineffective } \\
\text { erythropoiesis }\end{array}$} \\
\hline & Total & $\begin{array}{l}\left.\text { (BR } 1 \mathrm{~B}+\mathrm{BR}_{\mathrm{RBC}}\right) \\
\text { Total erythroid }\end{array}$ & $\begin{array}{l}\text { (BR } \mathrm{BBC}) \\
\text { Effective } \\
\text { erythropoiesis }\end{array}$ & $\begin{array}{l}\left.\text { (BR } \mathrm{BR}_{\mathrm{IR}}\right) \\
\text { Ineffective } \\
\text { erythropoiesis }\end{array}$ & \\
\hline $\begin{array}{l}\text { Control' (mean } \pm \text { 1SD) } \\
\text { Patient NE (CDA) }\end{array}$ & $\begin{array}{l}6.75 \pm 0.46 \\
40.35\end{array}$ & $\begin{array}{l}5.46 \pm 0.50 \\
39.05\end{array}$ & $\begin{array}{l}5.03 \pm 0.51 \\
19 \cdot 14\end{array}$ & $\begin{array}{l}0.45 \pm 0.17 \\
19.91\end{array}$ & $\begin{array}{l}8 \pm 3 \\
51\end{array}$ \\
\hline
\end{tabular}




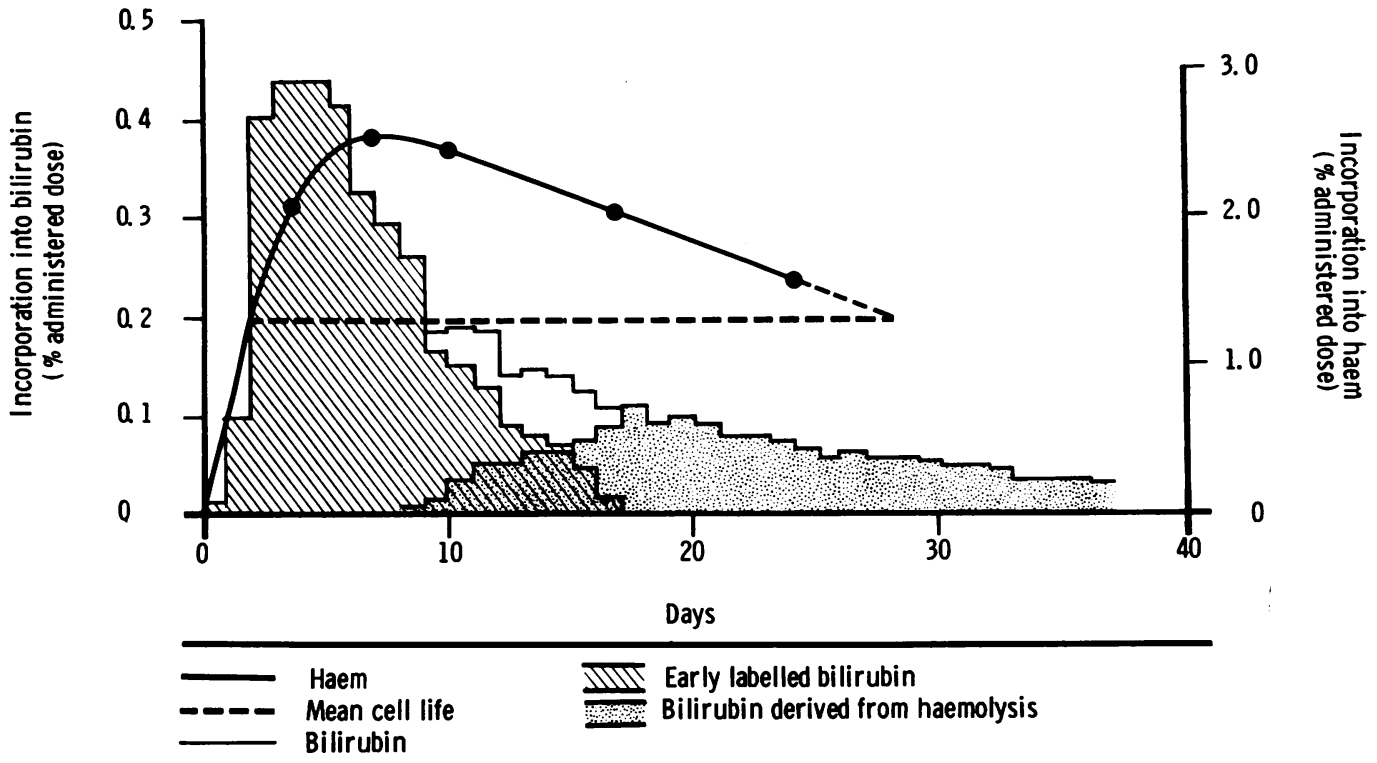

Fig. 5 Incorporation of ${ }^{15} \mathrm{~N}$ glycine into the haem of circulating red cells and into bilirubin.

abolished the transfusion requirement in this case, splenectomy prolonged the $\mathrm{T}_{\frac{1}{2}}{ }^{51} \mathrm{Cr}$ from 11 days to 21 days in one of the two patients described by Crookston et al. (1969).

The persistently low IgG level cannot be attributed to splenectomy since it was initially subnormal. In the majority of reported cases no data are available on immunoglobulin levels; normal or raised levels of immunoglobulins or of gamma globulin have been reported in a few cases (Schärer et al., 1965; Verwilghen et al., 1969; Bright et al., 1972), but lowimmunoglobulin levels have not been previously observed in association with CDA.

\section{QUANTITATION OF INEFFECTIVE \\ ERYTHROPOIESIS}

Conventional ferrokinetic studies confirm that ineffective erythropoiesis is an essential pathological feature of the congenital dyserythropoietic anaemias. Israels et al. (1959), Israels and Zipursky (1962), and Berendsohn et al. (1964) also described increased early labelled pigment production in disorders which appear to be forms of CDA, and Enquist et al. (1972) demonstrated a six-fold increase in carbon monoxide production in a case of CDA type II, only half of which could be accounted for by peripheral haemolysis. However, no quantitative estimates of ineffective erythropoiesis in this disorder have hitherto been made.

In the present case total erythroid haem turnover $\left(B_{I E}+B_{\text {BRBC }}\right)$ was increased six times compared with a control group. Haem turnover due to effective red cell production and destruction $\left(B_{R B C}\right)$ was increased three times, consistent with the reduction in mean cell life, but there was a disproportionate increase in haem turnover due to ineffective erythropoiesis $\left(B R_{I E}\right)$. $B R_{I E}$ was increased 45 times compared to the control group, a greater increase than that seen in a variety of haematological disorders including homozygous $\beta$-thalassaemia (Samson et $a l ., 1976 \mathrm{c}$ ) and pernicious anaemia (Samson et al., 1976a) and accounted for $51 \%$ of total erythroid haem turnover.

We are grateful to Dr Pauline Emerson for enzyme assays, to Dr S. N. Wickramasinghe for thymidine labelling studies, to $\mathrm{Dr}$ A. H. Maddy for electrophoretic analysis of red cell membrane, to $\mathrm{Dr} \mathbf{R}$. Dourmashkin for electron microscopy, and to Miss Eleanor Lloyd and Mr Warren Jones for serological studies. We thank Dr David Grant for permission to report this case.

\section{References}

Berendsohn, S., Lowman, J., Sundberg, D., and Watson, C. J. (1964). Idiopathic dyserythropoietic jaundice. Blood, 24, 1-18.

Bergström, I. and Jacobsson, L. (1962). Hereditary benign erythroreticulosis. Blood, 19, 296-303.

Berk, P. D., Blaschke, T. F., Scharschmidt, B. F., Waggoner, J. G., and Berlin, N. I. (1976). A new approach to quantitation of the various sources of bilirubin in man. Journal of Laboratory and Clinical Medicine, 87, 767-780. 
Bright, M., Cobb, J., Evans, B., and Parry, T. E. (1972). Congenital dyserythropoietic anaemia with erythroblastic multinuclearity. Journal of Clinical Pathology, 25, 561-569.

Crookston, J. H., Crookston, M. C., Burnie, K. L., Francombe, W. H., Dacie, J. V., Davis, J. A., and Lewis, S. M. (1969). Hereditary erythroblastic multinuclearity associated with a positive acidified-serum test: a type of congenital dyserythropoietic anaemia. British Journal of Haematology, 17, 11-26.

Enquist, R. W., Gockerman, J. P., Jenis, E. H., Warkel, R. L., and Dillon, D. E. (1972). Type II congenital dyserythropoietic anemia. Annals of Internal Medicine 77, 371-376.

Garby, L. and Mollison, P. L. (1971). Deduction of mean red-cell life-span from ${ }^{51} \mathrm{Cr}$ survival curves. British Journal of Haematology, 20, 527-536.

Goudsmit, R., Beckers, D., de Bruijne, J. I., Engelfriet, C. P., James, J., Morselt, A. F. W., and Reynierse, E. (1972). Congenital dyserythropoietic anaemia, Type III. British Journal of Haematology, 23, 97-105.

Heimpel, H., Forteza-Vila, J., Queisser, W., and Spiertz, E. (1971). Electron and light microscopic study of the erythroblasts of patients with congenital dyserythropoietic anemia. Blood, 37, 299-310.

Heimpel, H. and Wendt, F. (1968). Congenital dyserythropoietic anaemia with karocrrhexis and multinuclearity of erythroblasts. Helvetica Medica Acta, 34, 103-115.

Israels, L. G., Suderman, H. J., and Ritzmann, S. E. (1959). Hyperbilirubinemia due to an alternate path of bilirubin production. American Journal of Medicine, 27, 693-702.

Israels, L. G. and Zipursky, A. (1962). Primary shunt hyperbilirubinaemia. Nature (London), 193, 73-74.

Samson, D., Halliday, D., and Chanarin, I. (1976a). Reversal of ineffective erythropoiesis following treatment in pernicious anaemia. British Journal of Haemotology, in press.
Samson, D., Halliday, D., Nicholson, D. C., ando Chanarin, I. (1976b). Quantitation of ineffective erythropoiesis from the incorporation of $\left[{ }^{15} \mathrm{~N}\right] \delta$-aminolaevulinic acid and $\left[{ }^{15} \mathrm{~N}\right]$ glycine into early labelled bilirubin. I. Normal subjects. British Journal of Haematology, 34, 33-44.

Samson, D., Halliday, D., Nicholson, D. C., and Chanarin, I. (1976c). Quantitation of ineffective erythropoiesis from the incorporation of $\left[{ }^{15} \mathrm{~N}\right] \delta$-amino- $\mathrm{D}$ laevulinic acid and $\left[{ }^{15} \mathrm{~N}\right]$ glycine into early labellect bilirubin. II. Anaemic patients. British Journal of Haematology, 34, 45-53.

Schärer, K., Marti, H. R., and Baumann, T. (1965) Konstitutionelle Anämie mit Kernteilungsstörung derw Erythroblasten. Schweizerische medizinische Wocher schrift, 95, 1511-1515.

Valentine, W. N., Konrad, P. N., and Paglia, D. E. (1973) Dyserythropoiesis, refractory anaemia, and "pre leukemia:" metabolic features of the erythrocytes:Blood, 41, 857-875.

Verwilghen, R. L., Lewis, S. M., Dacie, J. V., Crookston J. H., and Crookston, M. C. (1973). HEMPAS? Congenital dyserythropoietic anaemia (Type II) Quarterly Journal of Medicine, 42, 257-278.

Verwilghen, R., Verhaegen, H., Waumans, P., and Beert은 J. (1969). Ineffective erythropoiesis with morphologic ally abnormal erythroblasts and unconjugated hyperbilirubinaemia. British Journal of Haematology, $17 \overrightarrow{\underline{0}}$ 27-33.

Weatherall, D. J., Clegg, J. B., Knox-Macaulay, H. H. Bunch, C., Hopkins, C. R., and Temperley, I. J. (197) A genetically determined disorder with features bots of thalassaemia and congenital dyserythropoietico anaemia. British Journal of Haematology, 24, 681-702

Wolff, J. A. and Von Hofe, F. H. (1951). Familia erythroid multinuclearity. Blood, 6, 1274-1283.

Wendt, F. and Heimpel, H. (1967). Kongenitale dysery응 thropoetische Anämie bei einem zweieiigen Zwillings paar. Medizinische Klinik, 62, 172-177. 